\title{
Phylogenetic Analysis of 16S rRNA Genes and PCR Analysis of the nec1 Gene from Streptomyces spp. Causing Common Scab, Pitted Scab, and Netted Scab in Finland
}

\author{
Jan F. Kreuze, Sini Suomalainen, Lars Paulin, and Jari P. T. Valkonen
}

\begin{abstract}
First and fourth authors: Department of Plant Biology, Genetic Centre, P.O. Box 7080, Swedish University of Agricultural Sciences (SLU), S-750 07 Uppsala, Sweden; and second and third authors: Institute of Biotechnology, Viikki Biocenter, P.O. Box 56, FIN-00014 University of Helsinki, Finland.

Accepted for publication 24 February 1999.
\end{abstract}

\begin{abstract}
Kreuze, J. F., Suomalainen, S., Paulin, L., and Valkonen, J. P. T. 1999. Phylogenetic analysis of $16 \mathrm{~S}$ rRNA genes and PCR analysis of the nec1 gene from Streptomyces spp. causing common scab, pitted scab, and netted scab in Finland. Phytopathology 89:462-469.

The sequences of the 16S rRNA genes (nucleotides 29 to 1,521) from various Streptomyces strains pathogenic to potato were compared. These included 10 pathogenic Streptomyces strains isolated from potato scab lesions in Finland, the type strains of S. aureofaciens NRRL $2209^{\mathrm{T}}$ and $S$. lydicus ATCC $25470^{\mathrm{T}}$, 'S. griseus subsp. scabies' ATCC 10246, and two $S$. griseus strains that were originally deposited to the collection as pathogens. The nucleotide sequence ( $>94.5 \%$ sequence identity [SI]) and length (1,469 to 1,481 nucleotides) of the analyzed region varied. Phylogenetic analysis of 16S rRNA genes placed Finnish strains into three species, supported by previously characterized morphological and physiological traits. Six Finnish strains, including two strains that deviated from the others in

rRNA genes and were identified as S. scabies (99.9\% SI to S. scabies ATCC 49173). Three Finnish strains were identified as S. turgidiscabies, a species previously described only in Japan (99.9\% SI to S. turgidiscabies ATCC 700248). Finnish strain 317 and S. aureofaciens NRRL 2209 (99.8\% SI) were placed in a distinct phylogenetic cluster together with Kitosatospora spp., which suggests that $S$. aureofaciens may belong to the recently revived genus Kitosatospora. In pathogenicity tests, $S$. scabies caused characteristic symptoms of common scab, $S$. turgidiscabies caused mainly pitted scab, and $S$. aureofaciens caused netted scab and necrotic lesions on stolons of potato cultivars Bintje and Matilda in the greenhouse. The necl gene and the intergenic region between necl and the $5^{\prime}$ transposase pseudogene ORFtnp were successfully amplified by polymerase chain reaction from S. scabies ATCC 49173 and the pathogenic Finnish strains of S. scabies, but not from a nonpathogenic strain of $S$. scabies, three pathogenic and two nonpathogenic strains of $S$. turgidiscabies, and S. aureofaciens.
\end{abstract} one trait (no spiral sporophores or D-xylose utilization), had identical 16S
Scab diseases occur on potato worldwide and cause economically significant losses in yield (23). Streptomyces scabies causes a disease on potato tubers that was originally described with the name 'common scab.' The symptoms can consist of erumpent, superficial, or pitted lesions, depending on pathogen strain and cultivar susceptibility (18). Also, S. griseus (7), S. cinerochromogenes (1), S. corchorusii (1), S. aureofaciens (7), the more acidtolerant species $S$. acidiscabies (19), and $S$. turgidiscabies $(25,37)$ have been reported to cause symptoms similar to common scab. Although highly virulent strains of $S$. scabies can cause pitted lesions in susceptible cultivars (23), such lesions are typical for another species named $S$. caviscabies (12), which occurs under high-moisture conditions in Canada. Furthermore, Archuleta and Easton (1) reported four other Streptomyces spp. (S. diastatochromogenes, S. atroolivaceus, S. lydicus, and S. resistomycificus) to be causal agents of deep-pitted scab in the state of Washington. The names 'russet scab' and 'netted scab' are used on the American continent and in Europe, respectively, to describe similar superficial symptoms on potato tubers. Russet scab and netted scab have, however, been shown to differ in several characteristics such as cultivar susceptibility, root attack, and optimum soil temperature and are, therefore, considered to be different diseases and can probably be caused by several Streptomyces spp. (31). Some of the strains causing russet scab have been placed into the $S$. aureo-

Corresponding author: J. P. T. Valkonen; E-mail address: jari.valkonen@ vbiol.slu.se

Publication no. P-1999-0325-01R

(C) 1999 The American Phytopathological Society faciens cluster of Williams et al. (39) by Faucher et al. (11). Streptomyces strains that cause netted scab in acidic and moist soils under cool conditions in Sweden are divided into two groups, one of which tolerates lower $\mathrm{pH}$ than does S. scabies (2). Pathogenic streptomycetes isolated from potato scab lesions in Israel belong to a phenotypically diverse population of Streptomyces spp. assigned to different phena (8).

In a recent study (21), Streptomyces strains isolated from scab lesions on potato tubers in Finland were characterized for colony color, sporophore morphology, pigment production, utilization of the International Streptomyces Project (ISP) sugars (32), growth under acidic conditions, and pathogenicity indicated by an ability to induce necrosis on potato minitubers $(5,20)$. Based on these criteria, most pathogenic strains were identical to S. scabies (18). Another large group of strains (designated group 4) distinguishable from $S$. scabies had flexuous sporophores, did not produce melanin, had tan colonies, utilized all ISP sugars, and grew at $\mathrm{pH}$ 4.4 , in contrast to $S$. scabies, which did not grow at or below $\mathrm{pH}$ 4.6. Most group 4 strains were nonpathogenic. Three pathogenic strains of this group $(287,298$, and 300) and one Finnish strain of S. scabies (SSC 101) have been tested in the greenhouse and shown to kill the sprouts of presprouted tubers of potato cultivars Bintje and Matilda, which were planted in washed sand previously inoculated with these strains (J. P. T. Valkonen, unpublished data). The whole-cell fatty acid composition of these group 4 strains clearly differs from that of S. scabies and S. acidiscabies (21). Strain 317 was able to cause necrosis on potato minitubers, but differed from the group 4 strains in that it had yellow colonies on yeast malt extract (YME) medium and did not grow at $\mathrm{pH} 4.4$ (21). 
16S rRNA gene sequences are an important criterion in microbial taxonomy (33), including that of the actinomycetes (34). The aim of this study was to determine $16 \mathrm{~S}$ rRNA gene sequences in selected Finnish Streptomyces strains that differ in physiological and morphological characteristics but are able to induce necrosis on potato minitubers (21). Additionally, 16S rRNA genes from five type strains of three Streptomyces species were sequenced in order to extend the number of plant-pathogenic Streptomyces spp. for which the 16S rRNA sequences are known and to permit a more comprehensive comparison between the Finnish strains and previously described species. Selected Finnish strains representing different phenetic groups were also tested for the type of symptoms they produced on potatoes in the greenhouse. Primers designed to amplify the genetic region ORFtnp-necl, which is linked to thaxtomin production and pathogenicity in S. scabies $(5,6)$, were tested as markers for pathogenicity of Finnish Streptomyces strains representing three different species.

\section{MATERIALS AND METHODS}

Streptomyces strains. Streptomyces strains analyzed in this study are listed in Table 1. The strains from Finland were isolated from scab lesions on field-grown potato tubers from different geographic locations and were previously characterized (21). Three Finnish strains of $S$. scabies, each differing from the $S$. scabies type strain $\left({ }^{\mathrm{T}}\right)$ ATCC $49173^{\mathrm{T}}$ (18) by only one taxonomic trait, were also included. Strains 364 and 380 are pathogenic (21). Strain 380 produces flexuous rather than spiral sporophores on YME medium of the ISP (32), and strain 364 does not utilize Dxylose. Strain 346 is nonpathogenic and does not utilize D-mannitol. The origins of the other Streptomyces strains included in this study are given in Table 1.

DNA isolation. Streptomyces strains were maintained on potato dextrose agar (PDA) (Difco Laboratories, Detroit) at $4^{\circ} \mathrm{C}$. For DNA isolation, they were grown on PDA at $24^{\circ} \mathrm{C}$ for 2 weeks, scraped from the PDA plate, and ground in liquid nitrogen. DNA isolation was carried out using the method provided by M. Kokkola. Frozen bacteria (200 to $500 \mathrm{mg}$ ) was transferred to a 2-ml microcentrifuge tube containing $500 \mu \mathrm{l}$ of TENP buffer $(50 \mathrm{mM}$ Tris, $\mathrm{pH} 8.0 ; 20 \mathrm{mM}$ EDTA, $\mathrm{pH} 8.0 ; 100 \mathrm{mM} \mathrm{NaCl}$; and $1 \%$ polyvinylpyrrolidone) and $150 \mu \mathrm{l}$ of $10 \%$ sodium dodecyl sulfate. After brief vortexing, the tube was dipped into liquid nitrogen, incubated at $100^{\circ} \mathrm{C}$ for $5 \mathrm{~min}$ and at $65^{\circ} \mathrm{C}$ for $60 \mathrm{~min}$, and then centrifuged at

TABLE 1. Streptomyces and Kitosatospora strains analyzed in this study

\begin{tabular}{|c|c|c|c|c|c|}
\hline \multirow[b]{2}{*}{ Strain } & \multirow[b]{2}{*}{ Origin $^{\mathrm{a}}$} & \multirow{2}{*}{$\begin{array}{c}\text { Group } \\
\text { assignment }^{b}\end{array}$} & \multicolumn{3}{|c|}{ 16S rRNA sequence } \\
\hline & & & Reference & Length of sequence $^{c}$ & Database accession numbers ${ }^{\mathrm{d}}$ \\
\hline \multicolumn{6}{|l|}{ Pathogenic Finnish strains } \\
\hline SSC 101 & Finland & $1 \mathrm{a}$ & This study & 1,477 & Y15493 \\
\hline 267 & Finland & $1 \mathrm{a}$ & This study & 1,477 & Y15500 \\
\hline 289 & Finland & $1 \mathrm{a}$ & This study & 1,477 & Y15509 \\
\hline 302 & Finland & $1 \mathrm{a}$ & This study & 1,477 & Y15508 \\
\hline 364 & Finland; DSM 41744 & $1 b$ & This study & 1,477 & Y15497 \\
\hline 380 & Finland & 3 & This study & 1,477 & Y15506 \\
\hline 287 & Finland; DSM 41745 & 4 & This study & 1,479 & Y15495 \\
\hline 298 & Finland; DSM 41746 & 4 & This study & 1,479 & Y15496 \\
\hline 300 & Finland; DSM 41747 & 4 & This study & 1,479 & Y15499 \\
\hline 317 & Finland; DSM 41743 & 5 & This study & $1,469^{\mathrm{e}}$ & Y15505 \\
\hline \multicolumn{6}{|l|}{ Nonpathogenic Finnish strains } \\
\hline 346 & Finland & $1 b$ & & & \\
\hline 268 & Finland & 4 & & & \\
\hline 283 & Finland & 4 & & & \\
\hline \multicolumn{6}{|l|}{ Reference strains } \\
\hline S. acidiscabies & ATCC $49003^{\mathrm{T}}$ & & 37 & 1,478 & D63865 \\
\hline S. ambofaciens & ATCC $23877^{\mathrm{T}}$ & & 28 & 1,478 & AF008220 \\
\hline S. aureofaciens & NRRL $2209^{\mathrm{T}}$ & & This study & $1,469^{\mathrm{e}}$ & Y15504 \\
\hline S. bottropensis & ATCC $25435^{\mathrm{T}}$ & & 37 & 1,478 & D63868 \\
\hline S. coelicolor & $\mathrm{A} 3(2)$ & & 3 & 1,478 & Y00411, M35377 \\
\hline S. diastatochromogenes & ATCC $12309^{\mathrm{T}}$ & & 37 & 1,479 & D63867 \\
\hline S. eurythermus & ATCC $14975^{\mathrm{T}}$ & & 37 & 1,478 & D63870 \\
\hline S. griseus (1) & H. Schrempf, Germany & & This study & 1,478 & Y15502 \\
\hline S. griseus (2) & ATCC 10137, R. Loria, United States & & This study & 1,478 & Y15501 \\
\hline S. griseus subsp. griseus & КСТC 9080 & & 16 & 1,476 & X55435 \\
\hline 'S. griseus subsp. scabies' & ATCC 10246, R. Loria, United States & & This study & 1,479 & Y15503 \\
\hline S. lividans & TK 21 & & 36 & 1,474 & Y00484 \\
\hline S. lydicus & ATCC $25470^{\mathrm{T}}$ & & This study & 1,481 & Y15507 \\
\hline S. neyagawaensis & ATCC $27449^{\mathrm{T}}$ & & 37 & 1,478 & D63869 \\
\hline S. sampsonii & ATCC $19812^{\mathrm{T}}$ & & 37 & 1,478 & D63861 \\
\hline S. scabies & ATCC $49173^{\mathrm{T}}$ & & 37 & 1,478 & D63862 \\
\hline S. setonii & ATCC $25497^{\mathrm{T}}$ & & 37 & 1,480 & D63872 \\
\hline S. tendae & ATCC $19812^{\mathrm{T}}$ & & 37 & 1,479 & D63873 \\
\hline S. turgidiscabies & ATCC $700248^{\mathrm{T}}$ & & 37 & 1,478 & D63866 \\
\hline K. azaticus & IFO 13803 & & 40 & 1,475 & U93312 \\
\hline K. brunnae & IFO 14879 & & 40 & $1,469^{\mathrm{e}}$ & U93314 \\
\hline K. griseola & JCM 3339 & & R. K. Wilson ${ }^{\mathrm{f}}$ & $1,468^{\mathrm{e}}$ & N55221 \\
\hline K. mediocidica & IFO 14879 & & 40 & 1,476 & U93324 \\
\hline$K$. setae & JCM 3304 & & R. K. Wilson ${ }^{\mathrm{f}}$ & 1,473 & N55220 \\
\hline
\end{tabular}

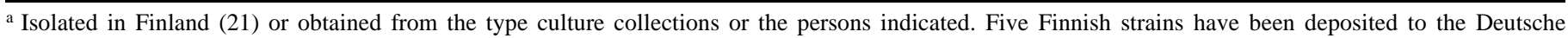
Sammlung für Mikroorganismen und Zellkulturen (DSM).

b Assigned to these strain groups by Lindholm et al. (21) based on phenotypical and physiological data.

${ }^{c}$ Length of 16S rRNA gene sequences excluding the first 29 nucleotides and the last 23 nucleotides of the $16 \mathrm{~S}$ rRNA gene.

${ }^{\mathrm{d}}$ GenBank/EMBL/DDBJ nucleotide sequence accession numbers.

e Sequences lack nucleotides 1,135 to 1,141 (Escherichia coli numbering) (4).

f Unpublished data. 
$8,000 \times g$ for $2 \mathrm{~min}$. The supernatant was transferred to a new tube, and the remaining cell debris was washed twice by resuspension in TENP buffer and centrifuged at $8,000 \times g$ for 2 min. All the supernatants were finally combined, $7 \mu \mathrm{l}$ of RNase A $(10 \mu \mathrm{g} / \mu \mathrm{l})$ was added, and the tube was incubated at $37^{\circ} \mathrm{C}$ for $30 \mathrm{~min}$. RNase
A (and other protein contaminants) were removed by two subsequent phenol/chloroform extractions. DNA was precipitated by adding 0.6 volume of ice-cold isopropanol and centrifuged at $8,000 \times g$ for $15 \mathrm{~min}$. The supernatant was discarded and the pellet washed in $70 \%$ ethanol and then redissolved in $40 \mu \mathrm{l}$

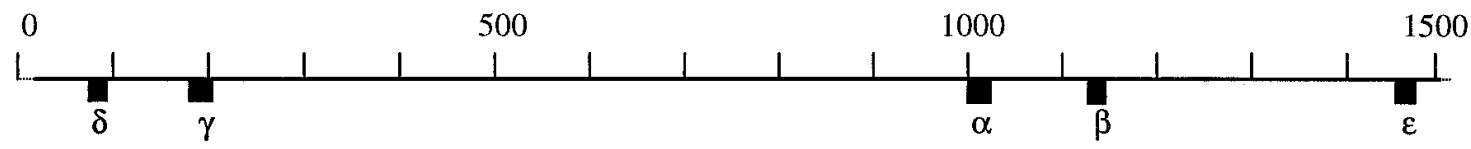

S.scabies
SSc101
$\mathbf{2 6 7}$
$\mathbf{2 8 9}$
$\mathbf{3 0 2}$
$\mathbf{3 6 4}$
$\mathbf{3 8 0}$
S.diastatochromogenes
$\mathbf{2 8 7}$
$\mathbf{2 9 8}$
$\mathbf{3 0 0}$
S.turgidiscabies
S.aureofaciens
$\mathbf{3 1 7}$
K. setae
K.griseola
S.setonii
S.griseus griseus
S.griseus (1)
S.griseus (2)
S.griseus scabies'
S.tendae
S.1ydicus
S.acidiscabies

$\delta^{*}$

$\gamma$

\begin{tabular}{|c|c|}
\hline \multirow{2}{*}{\multicolumn{2}{|c|}{$\begin{array}{lrrr}71 & 102 & 181 & 213 \\
\text { ATGAACCA-1.-.-CTTCGG-TGGGGATTA......TAC-GACACTCTCGGGCATCCGATGAGTGTGGA... }\end{array}$}} \\
\hline & \\
\hline & \\
\hline & \\
\hline & . \\
\hline & \\
\hline & $\ldots-A \ldots \ldots \ldots \ldots$ \\
\hline & $\ldots$ AAC $\ldots$-AG $\ldots \ldots$ TC \\
\hline$---\mathrm{T}$. & . А-T. . СТ. .С.TC... \\
\hline$---T$ & $\ldots A-T \ldots C T \ldots$ C.TC . . \\
\hline$--m$ & . A-T. .CT..C. \\
\hline--9 & . A-T. .CT. .C \\
\hline .c. & $\ldots \mathrm{T}-\ldots \mathrm{CT} \ldots \mathrm{C}$ \\
\hline C------. & . .T- . . . . СТСС .... \\
\hline$-\cdots--\cdots$ & $\ldots-\ldots \mathrm{C}$ \\
\hline$--\cdots---$ & . T- . . СТ . . СT . . . \\
\hline$. \mathrm{CG}---$ & . A-C. .T. .G. .CC . . .GG. .C. \\
\hline & . A-C. .T. .G. CC . . . GG. .C. \\
\hline & . A-C..T. .G. .CC \\
\hline :C-D...-T. & 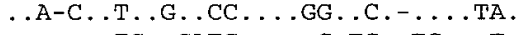 \\
\hline$---T$ & $\ldots$....TG. . САTC ....-G.TG. .TG...T \\
\hline & ..T......G.A....-.TGC..GT.C. \\
\hline 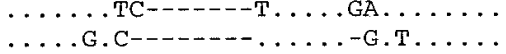 & T. CTG.CT . \\
\hline
\end{tabular}

$\alpha$

\begin{tabular}{|c|c|c|c|}
\hline 1025 & 1133 & 1143 & 1446 \\
\hline \multicolumn{4}{|c|}{ ACACCGGAAACGGCCAGAGATGGTCGC......CATGCCCTTCGGGGTGATG } \\
\hline$\cdots$ & & & $c \ldots \ldots \ldots \ldots-$ \\
\hline & & & $c \ldots \ldots \ldots,--\ldots$ \\
\hline …… & & & $\ldots \ldots \ldots$ \\
\hline & & & $C \ldots \ldots \ldots--$. \\
\hline & & & $\cdots$ \\
\hline & & & .C.T-GT... \\
\hline$\ldots \ldots \ldots$ AT $\ldots \ldots \ldots$ GT. & & & . C.C.CG... \\
\hline$\ldots \ldots \ldots$ AT $\ldots \ldots \ldots$. & & & C....C.C.CG $\ldots$... \\
\hline$\ldots \ldots \ldots$ AT. . & & & C.....C.C.CG.... \\
\hline$\ldots \ldots \ldots$ AT $\ldots \ldots \ldots$ GT. & & & C..-..C.T.CG.. \\
\hline TG......AT......... &. G-- & $\cdots 1$ & $\ldots \ldots \ldots-\ldots$ T. \\
\hline TG. . . . . . AT. . . . . . . GT. & $. G--$ & $\mathrm{TO}$ & $\ldots \ldots \ldots \ldots-\ldots T^{T}$ \\
\hline ..... T & ... & & ....G. $-\cdots$. GA. \\
\hline ...... . . . . . A.CA . & $. \mathrm{G}--$ &. $\mathrm{Td}$ & $\ldots \ldots \ldots-\ldots$ GA \\
\hline T...... GCAT. . . . . . GC. & & & C......T-GT.... \\
\hline . . . GCAT. . . . . GC. & $\cdots$ & & C......T-GT.... \\
\hline . . . . GCAT . . . . . . GC. & . & & C....C.T-GT.... \\
\hline Г......GCAT . . . . . GC. & . & & C......T-GT... \\
\hline …...T.TG...CA.G... & . G. & & C......T-GT... \\
\hline …..GCAT. & .G. & . C & C......T-GT.. \\
\hline ........ACC.TG. . . . CA.GGT. & & & . C.T-GT... \\
\hline & & & . C.T-GT... \\
\hline
\end{tabular}

Fig. 1. Sequence alignment of the major variable regions $(\delta, \gamma, \alpha, \beta$, and $\varepsilon)$ of $16 \mathrm{~S}$ rRNA genes of 10 Streptomyces strains isolated from potato scab lesions in Finland (bold), other strains of Streptomyces species reported to infect potato, and two Kitosatospora spp. Sequences are aligned with the sequence of $S$. scabies ATCC $49173^{\mathrm{T}}$, but the nucleotide numbers correspond to the 16S rRNA gene of Escherichia coli (4). The 16S rRNA gene of $E$. coli contains seven nucleotides that are missing in the $\delta$ region of the strains of Streptomyces and Kitosatospora species (indicated by dashes), whereas the eight nucleotides boxed in the $\beta$ region are missing in E. coli. The positions of the variable regions are indicated in the drawing of the 16S rRNA gene above the sequence alignment. Only the nucleotides different from S. scabies ATCC $49173^{\mathrm{T}}$ are shown, whereas identical nucleotides are indicated with dots. Deletions are indicated by dashes. The underlined sequences of strain 287 indicate the positions of primers specific to the Finnish strains of S. turgidiscabies (described in text). 
of sterile distilled water. This procedure usually yielded 1 to $2 \mu \mathrm{g}$ of DNA.

Polymerase chain reaction (PCR) amplification, sequencing, and phylogenetic analysis of 16S rRNA genes. The $16 \mathrm{~S}$ rRNAencoding sequence was amplified as two partially overlapping fragments using the previously described primer pairs $\mathrm{pA}-\mathrm{pE}^{\prime}$ and $\mathrm{pA}-\mathrm{pF}^{\prime}(9)$ for the $5^{\prime}$ half and the primer pair $\mathrm{pH}^{\prime}-\mathrm{pC}$ (9) for the $3^{\prime}$ half of the gene. The reaction mix contained 50 pmol of each primer, $10 \mu \mathrm{mol}$ of each deoxyribonucleoside triphosphate, $10 \mathrm{mM}$ Tris- $\mathrm{HCl}$ ( $\mathrm{pH} 8.0$ ), $1.5 \mathrm{mM} \mathrm{MgCl}_{2}, 50 \mathrm{mM} \mathrm{KCl}, 0.1 \%$ Triton X100, 1 unit of DyNAzymeII DNA polymerase (Finnzymes OY, Espoo, Finland), and $100 \mathrm{ng}$ of total DNA. Sterile distilled water was added to a total volume of $100 \mu \mathrm{l}$ of reaction mixture. PCR amplification was carried out with a thermal cycler (PTC-150 Mini-

TABLE 2. Similarity matrix of 16S rRNA sequences of Streptomyces strains isolated from potato scab lesions in Finland and some reference strains of Streptomyces spp. and Kitosatospora spp.

\begin{tabular}{|c|c|c|c|c|c|c|c|c|c|c|c|c|c|c|c|c|c|c|c|c|c|c|c|}
\hline $\begin{array}{l}\text { Strain, isolate, or } \\
\text { species }\end{array}$ & $\begin{array}{c}K . \\
\text { griseola }\end{array}$ & $\begin{array}{c}K . \\
\text { setae }\end{array}$ & 317 & $\begin{array}{c}S . \\
\text { aureo- } \\
\text { faciens }\end{array}$ & 380 & $\begin{array}{l}\text { SSC } \\
101\end{array}$ & 289 & 302 & 267 & $\begin{array}{c}S \\
\text { scabies } \\
\text { (ATCC } \\
49173 \text { ) }\end{array}$ & $\begin{array}{l}\text { S. dia- } \\
\text { stato- } \\
\text { chromo- } \\
\text { genes }\end{array}$ & 364 & 298 & 287 & 300 & $\begin{array}{c}S . \\
\text { turgidi- } \\
\text { scabies }\end{array}$ & $\begin{array}{c}S . \\
\text { griseus } \\
\text { (2) }\end{array}$ & $\begin{array}{c}S . \\
\text { griseus } \\
\text { (1) }\end{array}$ & $\begin{array}{c}S . \\
\text { setonii }\end{array}$ & $\begin{array}{l}\text { S. } \\
\text { griseus } \\
\text { subsp. } \\
\text { griseus }\end{array}$ & $\begin{array}{c}\text { S. } \\
\text { acidi- } \\
\text { scabies }\end{array}$ & $\begin{array}{l}\text { 'S. } \\
\text { griseus } \\
\text { subsp. } \\
\text { scabies' }\end{array}$ & $\begin{array}{cc}S . & S . \\
\text { tendae } & \text { lydicus }\end{array}$ \\
\hline
\end{tabular}

K. griseola

$\begin{array}{lll}\text { K. setae } & 96.5 \\ 317 & 96.2\end{array}$

$317 \quad 96.2 \quad 95.6$

$\begin{array}{llll}\text { S. aureofaciens } \quad 96.1 & 95.4 & 99.8\end{array}$

$\begin{array}{lllll}380 & 93.8 & 94.4 & 95.8 & 95.8\end{array}$

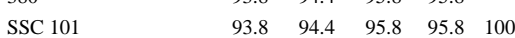

$\begin{array}{lllllll}289 & 93.8 & 94.4 & 95.8 & 95.8 & 100 & 100\end{array}$

$\begin{array}{llllllll}302 & 93.8 & 94.4 & 95.8 & 95.8 & 100 & 100 & 100\end{array}$

$\begin{array}{lllllllll}267 & 93.8 & 94.4 & 95.8 & 95.8 & 100 & 100 & 100 & 100\end{array}$

$\begin{array}{llllllllll}\text { S. scabies (ATCC 49173) } & 94.0 & 94.4 & 95.9 & 95.9 & 99.9 & 99.9 & 99.9 & 99.9 & 99.9\end{array}$

$\begin{array}{lllllllllll}364 & 93.8 & 94.4 & 95.8 & 95.8 & 100 & 100 & 100 & 100 & 100 & 99.9\end{array}$

$\begin{array}{lllllllllll}\text { S. diastatochromogenes } & 93.6 & 94.5 & 95.4 & 95.4 & 99.2 & 99.2 & 99.2 & 99.2 & 99.2 & 99.1\end{array}$

$\begin{array}{lllllllllll}298 & 94.3 & 94.6 & 96.9 & 96.9 & 97.7 & 97.7 & 97.7 & 97.7 & 97.7 & 97.6\end{array}$

$\begin{array}{llllllllllll}287 & 94.3 & 94.6 & 96.9 & 96.9 & 97.7 & 97.7 & 97.7 & 97.7 & 97.7 & 97.6\end{array}$

300

S. turgidiscabies

$\begin{array}{llllllllll}94.3 & 94.6 & 96.9 & 96.9 & 97.7 & 97.7 & 97.7 & 97.7 & 97.7 & 97.6\end{array}$

$\begin{array}{lllllllllll}94.3 & 94.6 & 96.9 & 96.9 & 97.7 & 97.7 & 97.7 & 97.7 & 97.7 & 97.7\end{array}$

S. griseus (2)

S. griseus (1)

$\begin{array}{lllllllllll}94.0 & 94.5 & 96.1 & 96.1 & 97.0 & 97.0 & 97.0 & 97.0 & 97.0 & 97.0\end{array}$

$\begin{array}{llllllllll}94.0 & 94.5 & 96.1 & 96.1 & 97.0 & 97.0 & 97.0 & 97.0 & 97.0 & 97.0\end{array}$

S. setonii

$\begin{array}{lllllllllll}94.1 & 94.5 & 96.3 & 96.2 & 97.2 & 97.2 & 97.2 & 97.2 & 97.2 & 97.2\end{array}$

$\begin{array}{lllllllllll}\text { S. griseus subsp. griseus } & 94.0 & 94.5 & 96.1 & 96.0 & 97.0 & 97.0 & 97.0 & 97.0 & 97.0 & 97.1\end{array}$

$\begin{array}{lllllllllll}\text { S. acidiscabies } & 93.8 & 95.1 & 95.8 & 95.7 & 97.5 & 97.5 & 97.5 & 97.5 & 97.5 & 97.5\end{array}$

$\begin{array}{lllllllllll}\text { 'S. griseus subsp. scabies' } & 92.7 & 93.0 & 94.9 & 94.9 & 95.7 & 95.7 & 95.7 & 95.7 & 95.7 & 95.7\end{array}$

$\begin{array}{lllllllllll}\text { S. tendae } & 92.4 & 92.8 & 94.5 & 94.5 & 96.3 & 96.3 & 96.3 & 96.3 & 96.3 & 96.4\end{array}$

$\begin{array}{lllllllllll}\text { S.lydicus } & 92.9 & 93.4 & 94.9 & 94.8 & 96.3 & 96.3 & 96.3 & 96.3 & 96.3 & 96.3\end{array}$

99.2
97.4
97.4
97.4
97.5
96.8
96.8
97.1
96.9
97.5
96.0
96.2
96.3

97.7

$97.7 \quad 100$

$97.7 \quad 100 \quad 100$

$\begin{array}{llll}97.7 & 99.9 & 99.9 & 99.9\end{array}$

$\begin{array}{lllll}97.0 & 97.6 & 97.6 & 97.6 & 97.6\end{array}$

$\begin{array}{llllll}97.0 & 97.6 & 97.6 & 97.6 & 97.6 & 100\end{array}$

$\begin{array}{ccccccc}97.2 & 97.6 & 97.6 & 97.6 & 97.7 & 99.9 & 99.9\end{array}$

$\begin{array}{llllllll}97.0 & 97.6 & 97.6 & 97.6 & 97.6 & 100 & 100 & 99.9\end{array}$

$\begin{array}{lllllllll}97.5 & 97.2 & 97.2 & 97.2 & 97.3 & 97.2 & 97.2 & 97.4 & 97.3\end{array}$

$\begin{array}{llllllllll}95.7 & 96.6 & 96.6 & 96.6 & 96.7 & 95.6 & 95.6 & 95.5 & 95.6 & 96.6\end{array}$

$\begin{array}{lllllllllll}96.3 & 96.1 & 96.1 & 96.1 & 96.3 & 96.3 & 96.3 & 96.5 & 96.4 & 96.9 & 97.8\end{array}$

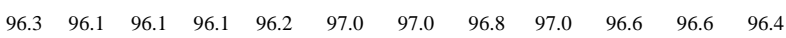

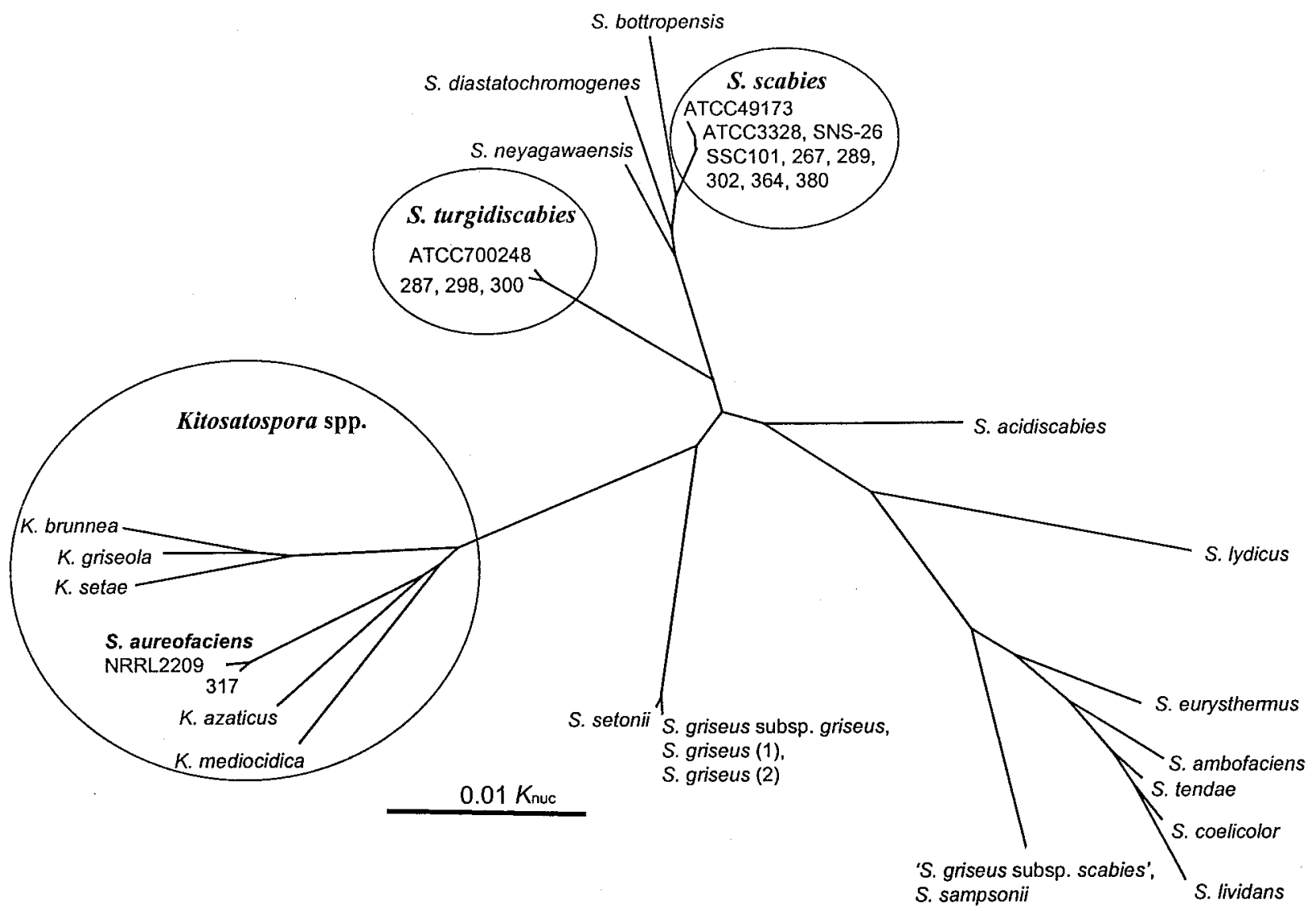

Fig. 2. Phylogenetic tree derived from $16 \mathrm{~S}$ rRNA gene sequences of Streptomyces spp. and Kitosatospora spp. Scale indicates the Kimura nucleotide distance ( $\left.K_{\text {nuc }}\right)$. 
Cycler with Hot-bonnet; MJ Research, Watertown, MA) using the following program: initial denaturation for $3 \mathrm{~min}$ at $95^{\circ} \mathrm{C}$, followed by 35 cycles consisting of denaturation for $30 \mathrm{~s}$ at $95^{\circ} \mathrm{C}$, annealing for $30 \mathrm{~s}$ at $55^{\circ} \mathrm{C}$, and DNA synthesis for $80 \mathrm{~s}$ at $72^{\circ} \mathrm{C}$. A final extension of $3 \mathrm{~min}$ at $72^{\circ} \mathrm{C}$ was added at the end of the $35 \mathrm{cy}$ cles. The sequence of the amplified product was determined by direct sequencing of both strands using the solid phase method described previously (29). Sequencing reactions were analyzed using an automated DNA sequencer (ALFexpress; Pharmacia Biotechnology, Uppsala, Sweden).

PCR-amplified 16S rRNA genes of the nonpathogenic strains were not sequenced, but they were analyzed by restriction with endonucleases $A l u \mathrm{I}, \mathrm{MboI}$ (Fermentas, Vilnius, Lithuania), and HaeIII (New England Biolabs, Beverly, MA). In addition, strains previously placed in group 4 (21) were tested by PCR using speciesspecific primers 5'-CCTCGCATGGGGGTGGGTTA-3' (16S rRNA gene nucleotides 195 to 216) (Fig. 1) and 5'-CGACAGCTCCCTCCCCGTGA-3' (nucleotides 1,460 to 1,479 ), based on the $16 \mathrm{~S}$ rRNA gene sequences of the Finnish strains 287, 298, and 300
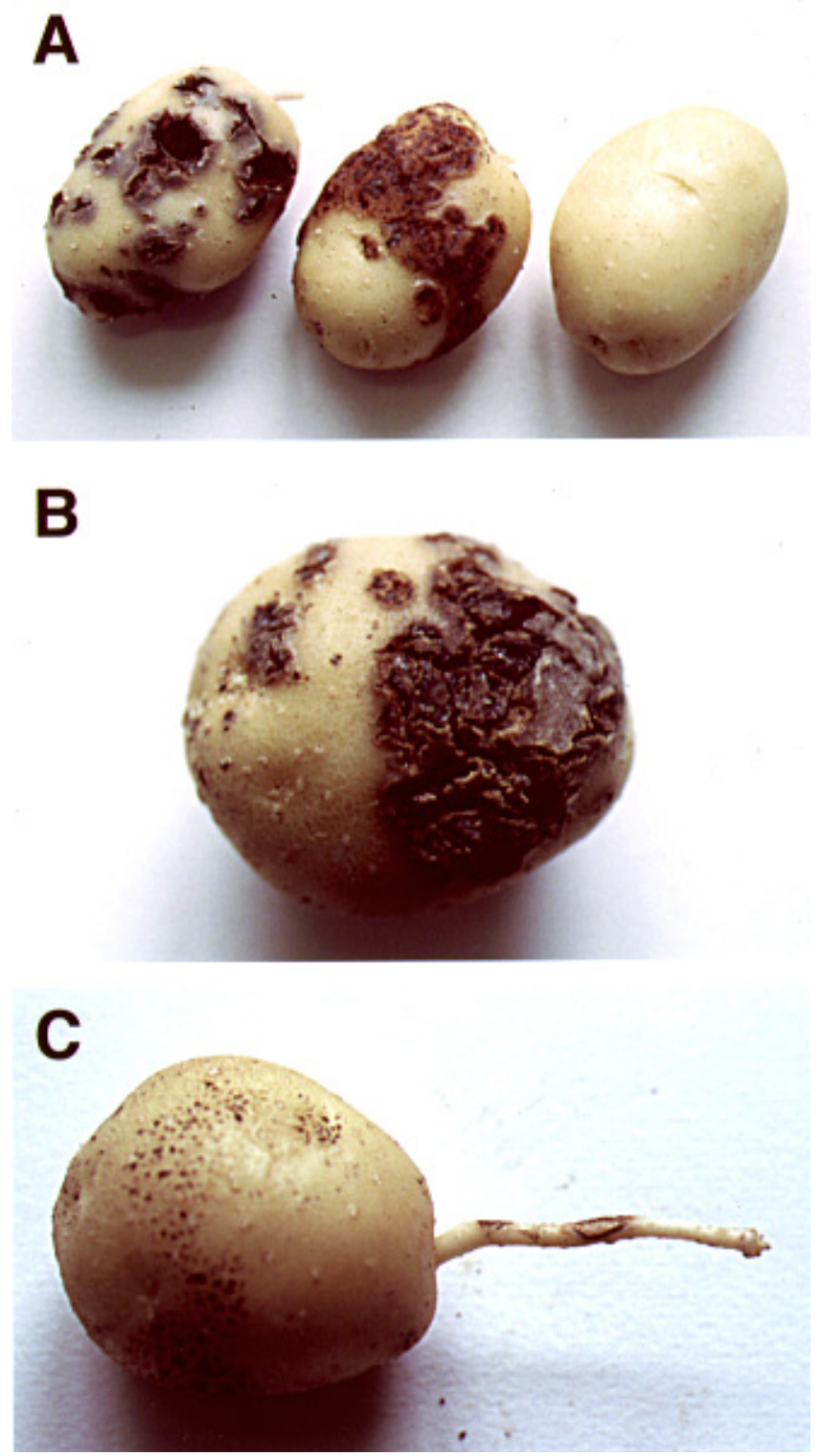

Fig. 3. A, Symptoms on tubers of potato 'Bintje' caused by strains 287 (Streptomyces turgidiscabies) (left) and 364 (S. scabies) (center). A tuber grown in noninoculated soil is to the right. $\mathbf{B}$, Severe symptoms caused by strain 298 (S. turgidiscabies) in potato 'Matilda'. C, Netted scab on the tuber and a necrotic lesion on a stolon of 'Bintje' caused by strain 317 (S. aureofaciens). Tubers in photographs appear approximately half of their natural size.
(Fig. 1). Strain 317 was tested by PCR with primers $5^{\prime}$-CCGTCGAAGGTGGGACCA-3' and 5'-TCCCTCAGGACCCAACAA-3', specific for Kitosatospora spp. (40).

Alignments and computer analyses of the DNA sequences were done using the Wisconsin Package software (version 8; Genetics Computer Group, Madison, WI). Sequences were aligned with the Pileup program. The alignments were used to calculate phylogenetic distances with the Distances program using the Kimura twoparameter model (17). A phylogenetic tree was compiled with the neighbor-joining method (30) using the Growtree program. Significance of the branch order was tested by 1,000 replications of bootstrap sampling of the original nucleotide sequence alignments by the Treecon program (38).

PCR amplification and restriction analysis of the necl gene and the ORFtnp-nec1 intergenic region. A previous study suggested that the necl gene of $S$. scabies can be used as a marker for pathogenicity in Streptomyces spp. (5). ORFtnp is a transposase pseudogene located upstream and separated by an intergenic region from necl. Sequences of these three regions form a genetic element that is reported to be identical in pathogenic $S$. scabies and $S$. turgidiscabies strains (5). necl and the intergenic region between ORFtnp and necl were amplified using the previously published PCR primers Nf-Nr and If-Ir, respectively. Primers If and Ir are targeted to an internal sequence of ORFtnp and necl, respectively (5). Amplified fragments were analyzed by restriction with endonucleases AluI, MboI, and HaeIII.

Pathogenicity tests. Strains 364 (S. scabies); 287, 298, and 300 (group 4); and 317 were grown in oatmeal broth (21) at $28^{\circ} \mathrm{C}$ with shaking $(150 \mathrm{rpm})$ for 10 days. After growth, the color of the broth was different for strain 364 (yellowish); 287, 298, and 300 (light brown); and 317 (cream). The cultures were diluted 1:1 with sterile distilled water, and $250 \mathrm{ml}$ was poured into a pot $(20-\mathrm{cm}$ diameter) filled with heat-sterilized greenhouse compost. Inoculum density of cultures was checked by dilution-plating on PDA and counting colonies (approximately $11 \times 10^{6} \mathrm{CFU}$ per $250 \mathrm{ml}$ ). Pathogen-free tubers of 'Bintje' and 'Matilda' (susceptible to netted scab and common scab) $(2,21,31)$ were obtained from the Seed Potato Center, Tyrnävä, Finland, and sprouted in dim light in the greenhouse for 2 weeks. One tuber was placed into each pot immediately after the inoculum had been mixed into the compost. Two pots of each cultivar were inoculated with each Streptomyces strain, and four pots of each cultivar were not inoculated (negative controls). Plants were grown in the greenhouse during January to May under natural daylight supplemented with illumination from fluorescent lamps (temperature 20 to $22^{\circ} \mathrm{C}$ ). Reisolation of inoculated bacteria from symptomatic tubers was carried out as previously described (21)

\section{RESULTS}

Analysis of 16S rRNA genes. The sequence corresponding to $16 \mathrm{~S}$ rRNA nucleotide positions 29 to 1,521 (according to the nomenclature of Escherichia coli) (4) was determined for 10 Streptomyces strains isolated from scab lesions on potato tubers in Finland (21). It was also determined for five additional Streptomyces strains isolated elsewhere that represented three species causing scab on potato. These sequences and the previously published $16 \mathrm{~S}$ rRNA gene sequences of other Streptomyces spp. $(16,37)$ reported to cause scab on potato were aligned (Fig. 1) with the corresponding sequence of $S$. scabies ATCC $49173^{\mathrm{T}}$ (37). The highly variable $\gamma$ region (nucleotides 181 to 213 ) and the less variable regions $\alpha$ (nucleotides 999 to 1,025 ) and $\beta$ (nucleotides 1,133 to 1,143 ) previously reported by Stackebrandt et al. (35) were detected (Fig. 1). Two additional regions designated $\delta$ (nucleotides 71 to 102) and $\varepsilon$ (nucleotides 1,446 to 1,464 ) also contained considerable variation (Fig. 1) not previously reported. When the entire sequenced region is taken into consideration, sequence identities (SI) among the Streptomyces spp. analyzed ranged from 94.5 to $100 \%$ (Table 2). 
However, the lengths of the 16S rRNA gene sequences varied among strains because of deletions or insertions (Table 1, Fig. 1).

Based on SI and phylogenetic analyses, the Finnish strains were placed into three groups (Fig. 2). Two of these groups consisted of strains with almost identical 16S rRNA sequences (99.9\% SI) within the group but differing by at least $0.8 \%$ from the strains in other groups. The first group included most of the Finnish strains $\left(267,289,302,364,380\right.$, and SSC 101), S. scabies ATCC 49173 ${ }^{\mathrm{T}}$, and the two other S. scabies strains, ATCC 33282 and SNS-26, analyzed by Takeuchi et al. (37). The Finnish strains were identical but differed from the latter-mentioned $S$. scabies strains at nucleotide positions $185(\mathrm{G} \rightarrow \mathrm{A})$ and $1,446(\mathrm{~T} \rightarrow \mathrm{C})$ and by a deletion of the nucleotide at position 1,458 (99.9\% SI) (Fig. 1, Table 2). The plant-pathogenic species $S$. diastatochromogenes ATCC $12309^{\mathrm{T}}$ was linked to this cluster $\left(99.1 \%\right.$ SI to $S$. scabies ATCC $\left.49173^{\mathrm{T}}\right)$.

The second group consisted of the Finnish strains 287, 298, and 300 (previously placed in group 4) (21) and the Japanese strain $S$. turgidiscabies ATCC $700248^{\mathrm{T}}$. Finnish strains were identical but differed from the Japanese strain of $S$. turgidiscabies at nucleotide positions $212(\mathrm{C} \rightarrow \mathrm{A})$ and $1,454(\mathrm{C} \rightarrow \mathrm{T})$ and the presence of nucleotide 1,449 (C) missing in the Japanese strain.

The Finnish strain 317 and S. aureofaciens NRRL 2209 ${ }^{\mathrm{T}}$ differed from each other at three nucleotide positions $(76[\mathrm{~A} \rightarrow \mathrm{G}], 77$ $[\mathrm{G} \rightarrow \mathrm{C}]$, and 1,475 $[\mathrm{T} \rightarrow \mathrm{C}]$ ) and grouped with Kitosatospora spp., forming a distinct cluster. The two strains of $S$. aureofaciens, $K$. brunnae IFO 14879 and K. griseola JCM 3339 (Table 1), lacked seven nucleotides (nucleotides 1,135 to 1,141 ). This gap was unique for these strains and existed in neither S. scabies ATCC $49173^{\mathrm{T}}$ nor any other strain analyzed in this study (Fig. 1). Furthermore, amplification of the 16S rRNA gene with the Kitosatospora-specific primers of Zhang et al. (40) resulted in amplification of a product from $S$. aureofaciens but not from $S$. scabies and $S$. turgidiscabies (data not shown).

$16 \mathrm{~S}$ rRNA sequences of the two strains of $S$. griseus included in this study were identical but contained two additional nucleotides $(1,137[\mathrm{C}]$ and 1,263 [C]) as compared with $S$. griseus subsp. griseus KCTC 9080 (16). Comparison of the two S. griseus strains to $S$. setonii ATCC $25497^{\mathrm{T}}$ (37) revealed two nucleotide changes (87 $[\mathrm{T} \rightarrow \mathrm{C}]$ and $465[\mathrm{G} \rightarrow \mathrm{A}]$ ) and two additional nucleotides (79 [G] and $93[\mathrm{~T}]$ ) in $S$. setonii. These four strains formed their own cluster.

The 16S rRNA gene sequence of ' $S$. griseus subsp. scabies' ATCC 10246 was identical to that of $S$. sampsonii ATCC $19812^{\mathrm{T}}$ (37). Their branch in the phylogenetic tree was linked to a larger branch of less-related species, of which S. lydicus contains plantpathogenic strains (1).

Symptoms in tubers. Strains 364 (S. scabies); 287, 298, and 300 (group 4); and 317 were tested for pathogenicity on 'Bintje' and 'Matilda'. All strains were pathogenic and caused symptoms, whereas tubers grown in noninoculated soil remained symptomless (Fig. 3). Strain 364 of S. scabies caused characteristic common scab symptoms (Fig. 3). Symptoms caused by strains 287, 298 , and 300 of S. turgidiscabies were identical. Lesions were black and pitted on 'Bintje' and pitted or superficial on 'Matilda' (Fig. 3). Symptoms caused by these three strains were clearly distinguishable from those caused by strain 364 in 'Bintje' (Fig. 3) but were more similar to those caused by strain 364 in 'Matilda'. Strain 317 of $S$. aureofaciens was not severe and caused only superficial necrosis resembling netted scab. Necrotic lesions developed on stolons of both cultivars (Fig. 3). This was not observed with strains 364, 287, 298, and 300.

PCR amplification and restriction analysis of the nec1 gene and the ORFtnp-nec1 intergenic region. necl and the intergenic region between necl and its $5^{\prime}$ transposase pseudogene ORFtnp are highly conserved and linked with thaxtomin production and pathogenicity in $S$. scabies and $S$. turgidiscabies, according to a previous study (5). necl and the intergenic region were successfully amplified by PCR from ATCC $49173^{\mathrm{T}}$ and pathogenic Finnish strains of $S$. scabies (including strains 364 and 380) using the originally described primers (5) (Fig. 4). Restriction analysis of the products revealed the expected pattern of fragments $(5,6)$, which was identical in all strains. In contrast, no product was obtained with the two pairs of primers from the nonpathogenic strain 346 of S. scabies; pathogenic strains 287, 298, and 300; and the nonpathogenic strains 268 and 283 of $S$. turgidiscabies and strain 317 of $S$. aureofaciens (Fig. 4).

\section{DISCUSSION}

Grouping of the 10 pathogenic Finnish Streptomyces strains based on phylogenetic analysis of $16 \mathrm{~S}$ rRNA gene sequences was supported by the previous grouping based on morphological and physiological traits (21) and indicated that the strains belonged to three previously described, plant-pathogenic species: S. scabies (strains SSC 101, 267, 289, 302, 364, and 380), S. turgidiscabies (strains 287, 298, and 300), and S. aureofaciens (strain 317). Most of the sequence variability was confined to five regions, namely the previously reported $\alpha, \beta$, and $\gamma$ regions (24) and the new $\delta$ and $\varepsilon$ regions detected in this study. The $\gamma$ region was the most variable of these regions. Our phylogenetic analysis was fully consistent with the previous study by Takeuchi et al. (37), which included fewer species and strains. Important new findings of this study included the 16S rRNA gene sequence-based phylogenetic positions of $S$. lydicus, the previously described strains and subspecies of $S$. griseus, and the placement of $S$. aureofaciens to the distinct phylogenetic cluster of Kitosatospora spp.

S. scabies is the most studied Streptomyces species infecting potato and is reported to show exceptionally broad intraspecific genetic diversity $(14,27)$. This study indicated that $16 \mathrm{~S}$ rRNA genes of $S$. scabies possess some, even though limited, intraspecific variability. The previous study of Takeuchi et al. (37) found
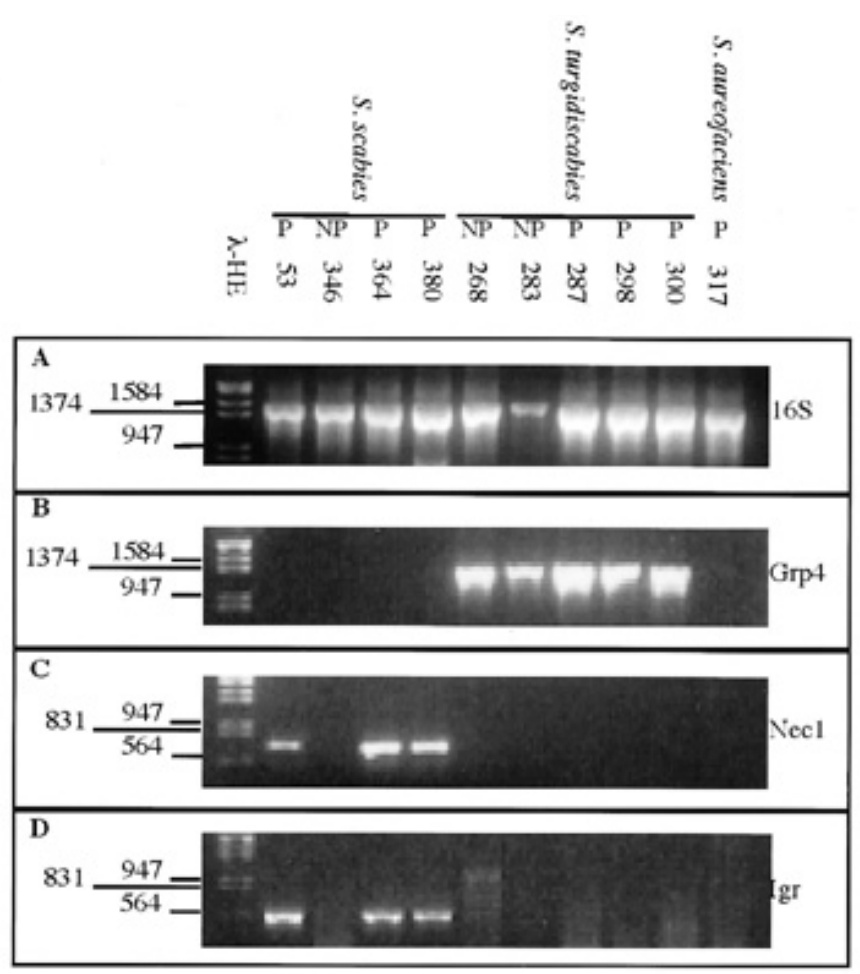

Fig. 4. Polymerase chain reaction amplification of the A, 16S rRNA gene using universal primers (9); B, 16S rRNA gene using the primers specific to Finnish strains of Streptomyces turgidiscabies designed in this study; $\mathbf{C}$, nec1 gene; and $\mathbf{D}$, intergenic region between ORFtnp and necl. $\mathrm{P}=$ pathogenic on potato; $\mathrm{NP}=$ nonpathogenic $; \lambda \mathrm{HE}=$ molecular marker (bacteriophage $\lambda$ DNA digested with HindIII and EcoRI; sizes in base pairs are indicated for selected fragments); $53=S$. scabies ATCC $49173^{\mathrm{T}} ; 346,364$, and $380=$ Finnish strains of S. scabies; 268, 283, 287, 298, and $300=$ Finnish strains of S. turgidiscabies; and $317=$ Finnish strain of S. aureofaciens. 
that 16S rRNA gene sequences in three strains of $S$. scabies with geographically different origins (Japan, Hungary, and United States) are identical except for one nucleotide position. While the $16 \mathrm{~S}$ rRNA genes of the six Finnish strains of $S$. scabies analyzed in this study were all identical, they differed from the three previously analyzed strains of S. scabies (37) at one or two nucleotide positions and had one additional nucleotide (99.9\% SI). Secondly, this study helped to clarify the taxonomic status of certain strains that have been previously considered to be deviant strains of $S$. scabies, based on morphological and physiological characterization. Such strains in previous studies included those not producing melanin pigment, not utilizing one of the ISP sugars, and lacking flexuous sporophores on YME, but possessing all other traits of $S$. scabies $(10,13,21)$. The $16 \mathrm{~S}$ rRNA gene sequence of the Japanese, deviant, non-melanin-producing strain SNS-26 of S. scabies is identical to the $16 \mathrm{~S}$ rRNA gene sequence of one melanin-producing strain (ATCC 3328) and differs by one nucleotide from $S$. scabies ATCC $49173^{\mathrm{T}}$ (37). Similarly, 16S rRNA gene sequences of Finnish strain 364, which does not utilize D-xylose, and strain 380 , which does not produce spiral sporophores on YME, were identical to the other four Finnish strains of S. scabies. The latter four strains, in turn, are identical to $S$. scabies ATCC $49173^{\mathrm{T}}$ for all tested physiological and morphological traits, except for some differences in their whole-cell fatty acid profiles (21). The characteristic common scab symptoms caused by strain 364 in 'Bintje' and 'Matilda' provided further evidence that this physiologically deviant strain belongs to $S$. scabies.

Strain 317 was identified as $S$. aureofaciens, because this strain and $S$. aureofaciens NRRL $2209^{\mathrm{T}}$ are phenotypically identical (12, 21 ), and they were placed in the same phylogenetic cluster based on $16 \mathrm{~S}$ rRNA gene sequences $(99.8 \% \mathrm{SI})$. The symptoms caused by strain 317 resembled netted scab or russet scab, both of which are similar (31), which also supports assignment of strain 317 to $S$. aureofaciens, reported to cause russet scab in North America $(12,23,31)$. Strain 317 was originally isolated from one farm in Loimaa, and similar strains have not been isolated elsewhere in Finland (21). To our knowledge, this is the first time $S$. aureofaciens has been reported in Europe.

$S$. aureofaciens was placed in the minor clustergroup 14 ( $S$. aureofaciens) by Williams et al. (39) and in subcluster 22-4 (S. misakiensis) by Kämpfer et al. (15). Both of the strains of $S$. aureofaciens in this study carried a 7-base pair (bp) deletion within the 16S rRNA gene, which has not been reported in any Streptomyces spp. but exists in two of the five Kitosatospora spp. included in this study (Fig. 1). Phylogenetic analysis of 16S rRNA genes placed $S$. aureofaciens and Kitosatospora spp. in the same distinct cluster (irrespective of the 7-bp deletion), and the Kitosatospora-specific primers (40) detected the 16S rRNA gene of only $S$. aureofaciens. When the $16 \mathrm{~S}$ rRNA gene sequence of $E$. coli (4) was included to root the phylogenetic tree, the phylogenetic branch formed by Kitosatospora spp. and $S$. aureofaciens became even more distinct (data not shown). These data were consistent with the phylogenetic analysis of Zhang et al. (40), which placed several other Streptomyces spp. in the same cluster with Kitosatospora spp. Our data indicate that $S$. aureofaciens may be a member of the recently revived genus Kitosatospora $(26,40)$.

$S$. turgidiscabies was recently found on the eastern side of Hokkaido island in Japan (37) and it has not been reported elsewhere (25). However, morphologically and physiologically similar pathogenic strains occur throughout a broad area in Finland (21). The 16S rRNA gene sequences of three Finnish strains were identical and differed from Japanese strain S. turgidiscabies ATCC $700248^{\mathrm{T}}$ (91-Sy-13) (37) at only three nucleotide positions (99.9\% SI). Thus, all four strains seem to belong to the same species. To our knowledge, this is the first study reporting the occurrence of $S$. turgidiscabies outside Japan. A recent study suggested that Japanese strains of $S$. turgidiscabies gained their pathogenicity factors from $S$. scabies (5). This conclusion was based on the presence of an iden- tical, virulence-associated genetic element in pathogenic strains of both species (data on nonpathogenic strains of the two species not shown). The genetic element consists of a transposase pseudogene (ORFtnp), a gene (necl) that allows nonpathogenic S. lividans to induce necrosis on potato tuber disks, and an intergenic region between these two genes. necl has been found in 23 and 15 pathogenic strains of $S$. scabies and $S$. turgidiscabies, respectively, except for one pathogenic strain of $S$. scabies from South Africa. Therefore, it has been proposed that PCR amplification of necl could be used as a marker for pathogenicity in Streptomyces spp. and might substitute for pathogenicity testing (5). Our data were consistent with this view as regards $S$. scabies. In contrast, neither necl nor the intergenic region could be amplified from the pathogenic Finnish strains of $S$. turgidiscabies and $S$. aureofaciens, which indicated that either the genetic element is not present or its sequence is not conserved in these strains. This needs to be resolved in further studies.

The pathogenicity of all Finnish Streptomyces strains of this study has been previously tested repeatedly (21) with the minituber method (20) as described by Loria et al. (22). Japanese strains of $S$. turgidiscabies have also been tested for pathogenicity with this method (5). Data on Japanese and Finnish strains of S. turgidiscabies are consistent in that $S$. turgidiscabies induces necrosis on potato minitubers $(5,21)$. The original report of $S$. turgidiscabies states that "scab symptoms caused by this pathogen (represented by strain 91-Sy-13) are indistinguishable from those caused by $S$. scabies" in mature potato tubers (37). However, in a more recent report, the symptoms caused by $S$. turgidiscabies in experimentally inoculated potatoes have been described as "erumpent, rough, corky lesions" and the symptoms on tubers in the field were described as "distinctly erumpent" (25). In our study, the Finnish strains of $S$. turgidiscabies caused mainly pitted lesions that were distinct from the symptoms caused by S. scabies and S. aureofaciens (Fig. 3). Discrepancies in the types of symptoms reported for $S$. turgidiscabies may be attributable to the different potato cultivars used in each study. For example, S. scabies is known to cause different symptoms (erumpent, superficial, or pitted lesions) depending on virulence of the pathogen strain and susceptibility of the potato cultivar (23). Alternatively, the different symptoms caused by the Finnish and Japanese strains and the possible absence of the ORFtnp-necl region in the Finnish strains suggests that they may use somewhat different pathogenicity factors, which remains to be investigated in future studies.

\section{ACKNOWLEDGMENTS}

We thank M. Kokkola for providing the method for DNA isolation, T. Laine for maintaining strains, and R. Loria and B. Fry for providing Streptomyces strains and information about the phenotypic traits of $S$. griseus subsp. scabies ATCC 10246 and S. griseus ATCC 10137. We also thank M. Lindberg and G. Wagner, Department of Microbiology (SLU), for critically reading the manuscript and Kalkitusyhdistys ry., Kemira Agro Oy, and Vapo Oy for financial support.

\section{LITERATURE CITED}

1. Archuleta, J. G., and Easton, G. D. 1981. The cause of deep-pitted scab of potatoes. Am. Potato J. 58:385-392.

2. Bång, H. 1979. Studies on potato russet scab. 1. A characterization of different isolates from northern Sweden. Acta Agric. Scand. 29:145-150.

3. Baylis, H. A., and Bibb, M. J. 1988. Transcriptional analysis of the $16 \mathrm{~S}$ rRNA gene of the $r r n D$ gene set of Streptomyces coelicolor A3(2). Mol. Microbiol. 2:569-579.

4. Brosius, J., Palmer, M. L., Kennedy, P. J., and Noller, H. F. 1978. Complete nucleotide sequence of a 16S ribosomal RNA gene from Escherichia coli. Proc. Natl. Acad. Sci. U.S.A. 75:4801-4805.

5. Bukhalid, R. A., Chung, S. Y., and Loria, R. 1998. nec1, a gene conferring a necrogenic phenotype, is conserved in plant-pathogenic Streptomyces spp. and linked to a transposase pseudogene. Mol. Plant-Microbe Interact. 11:960-967.

6. Bukhalid, R. A., and Loria, R. 1997. Cloning and expression of a gene 
from Streptomyces scabies encoding a putative pathogenicity factor. J. Bacteriol. 179:7776-7783.

7. Corbaz, R. 1964. Etude des streptomycètes provoquant la gale commune de la pomme de terre. Phytopathol. Z. 51:351-360.

8. Doering-Saad, C., Kämpfer, P., Manulis, S., Kritzman, G., Schneider, J., Zakrzewska-Czerwinska, J., Schrempf, H., and Barash, I. 1992. Diversity among Streptomyces strains causing potato scab. Appl. Environ. Microbiol. 58:3932-3940.

9. Edwards, U., Rogall, T., Blöcker, H., Emde, M., and Böttger, E. C. 1989. Isolation and direct complete determination of entire genes. Characterization of a gene coding for $16 \mathrm{~S}$ ribosomal RNA. Nucleic Acids Res. 17: 7843-7853.

10. Elesawy, A. A., and Szabó, I. M. 1979. Isolation and characterization of Streptomyces scabies strains from scab lesions of potato tubers. Designation of the neotype strain of Streptomyces scabies. Acta Microbiol. Acad. Sci. Hung. 26:311-320.

11. Faucher, E., Otrysko, B., Paradis, E., Hodge, N. C., Stall, R. E., and Beaulieu, C. 1993. Characterization of streptomycetes causing russet scab in Québec. Plant Dis. 77:1217-1220.

12. Goyer, C., Faucher, E., and Beaulieu, C. 1996. Streptomyces caviscabies sp. nov., from deep-pitted lesions in potatoes in Québec, Canada. Int. J. Syst. Bacteriol. 46:635-639.

13. Goyer, C., Otrysko, B., and Beaulieu, C. 1996. Taxonomic studies on streptomycetes causing potato common scab: A review. Can. J. Plant Pathol. 18:107-113.

14. Healy, F. G., and Lambert, D. H. 1991. Relationships among Streptomyces spp. causing potato scab. Int. J. Syst. Bacteriol. 41:479-482.

15. Kämpfer, P., Kroppenstedt, R. M., and Dott, W. 1991. A numerical classification of the genera Streptomyces and Streptoverticillium using miniaturized physiological tests. J. Gen. Microbiol. 137:1831-1891.

16. Kim, E., Kim, H., Hong, S., Kang, K. H., Kho, Y. H., and Park, Y. 1993. Gene organization and primary structure of a ribosomal RNA gene cluster from Streptomyces griseus subsp. griseus. Gene 132:21-31.

17. Kimura, M. 1980. A simple method for estimating evolutionary rates of base substitutions through comparative studies of nucleotide sequences. J. Mol. Evol. 16:111-120.

18. Lambert, D. H., and Loria, R. 1989. Streptomyces scabies sp. nov. Int. J. Syst. Bacteriol. 39:387-392.

19. Lambert, D. H., and Loria, R. 1989. Streptomyces acidiscabies sp. nov. Int. J. Syst. Bacteriol. 39:393-396.

20. Lawrence, C. H., Clark, M. C., and King, R. R. 1990. Induction of common scab symptoms in aseptically cultured potato tubers by the vivotoxin, thaxtomin. Phytopathology 80:606-608.

21. Lindholm, P., Kortemaa, H., Kokkola, M., Haahtela, K., Salkinoja-Salonen, M., and Valkonen, J. P. T. 1997. Streptomyces spp. isolated from potato scab lesions under Nordic conditions in Finland. Plant Dis. 81:1317-1322.

22. Loria, R., Bukhalid, R. A., Creath, R. A., Leiner, R. H., Olivier, M., and Steffens, J. C. 1995. Differential production of thaxtomins by pathogenic Streptomyces species in vitro. Phytopathology 85:537-541.
23. Loria, R., Bukhalid, R. A., Fry, B. A., and King, R. R. 1997. Plant pathogenicity in the genus Streptomyces. Plant Dis. 81:836-846.

24. Mehling, A., Wehmeier, U. F., and Piepersberg, W. 1995. Nucleotide sequences of streptomycete $16 \mathrm{~S}$ ribosomal DNA: Towards a specific identification system for streptomycetes using PCR. Microbiology 141:2139-2147.

25. Miyajima, K., Tanaka, F., Takeuchi, T., and Kuninaga, S. 1998. Streptomyces turgidiscabies sp. nov. Int. J. Syst. Bacteriol. 48:495-502.

26. Omura, S., Takahashi, Y., Iwai, Y., and Tanak, H. 1982. Kitosatospora, a new genus of the order Actinomycetales. J. Antibiot. 35:1013-1019.

27. Paradis, E., Goyer, C., Hodge, N. C., Hogue, R., Stall, R. E., and Beaulieu, C. 1994. Fatty acid and protein profiles of Streptomyces scabies strains isolated in eastern Canada. Int. J. Syst. Bacteriol. 44:561-564

28. Pernodet, J. L., Boccard, F., Alegre, M. T., Gagnat, J., and Guerineau, M. 1989. Organization and nucleotide sequence analysis of a ribosomal RNA gene cluster from Streptomyces ambofaciens. Gene 79:33-46.

29. Ridell, J., Siitonen, A., Paulin, L., Lindroos, O., Korkeala, H., and Albert, M. J. 1995. Characterization of Hafnia alvei with biochemical tests, RAPD-PCR and partial sequencing of the 16S rRNA gene. J. Clin. Microbiol. 33:2372-2376.

30. Saitou, N., and Nei, M. 1987. The neighbor-joining method: A new method for reconstructing phylogenetic trees. Mol. Biol. Evol. 4:406-425.

31. Scholte, K., and Labruyère, R. E. 1985. Netted scab: A new name for an old disease in Europe. Potato Res. 28:443-448.

32. Shirling, E. B., and Gottlieb, D. 1966. Methods for characterization of Streptomyces species. Int. J. Syst. Bacteriol. 16:313-340.

33. Stackebradt, E., and Goepel, B. M. 1994. Taxonomic note: A place for DNA-DNA reassociation and $16 \mathrm{~S}$ rRNA sequence analysis in the present species definition in bacteriology. Int. J. Syst. Bacteriol. 44:846-849.

34. Stackebrandt, E., Rainey, F. A., and Ward-Rainey, N. L. 1997. Proposal for a new hierarchic classification system, Actinobacteria classis nov. Int. J. Syst. Bacteriol. 47:479-491.

35. Stackebrandt, E., Witt, D., Kemmerling, C., Kroppenstedt, R., and Liesack, W. 1991. Designation of streptomycete 16S and 23S rRNA-based target regions for oligonucleotide probes. Appl. Environ. Microbiol. 57:1468-1477.

36. Suzuki, Y., Nagata, A., Ono, Y., and Yamada, T. 1988. Molecular cloning and characterization of an rRNA operon in Streptomyces lividans TK21. J. Bacteriol. 170:2886-2889.

37. Takeuchi, T., Sawada, H., Tanaka, F., and Matsuda, I. 1996. Phylogenetic analysis of Streptomyces spp. causing potato scab based on $16 \mathrm{~S}$ rRNA sequences. Int. J. Syst. Bacteriol. 46:476-479.

38. Van de Peer, Y., and De Wachter, R. 1994. TREECON for Windows: A software package for the construction and drawing of evolutionary trees for the Microsoft Windows environment. Comput. Appl. Biosci. 10:569-570.

39. Williams, S. T., Goodfellow, M., Alderson, G., Wellington, E. M. H., Sneath, P. H. A., and Sackin, M. J. 1983. Numerical classification of Streptomyces and related genera. J. Gen. Microbiol. 129:1743-1813.

40. Zhang, Z., Wang, Y., and Ruan, J. 1997. A proposal to revive the genus Kitosatospora (Omura, Takahashi, Iwai and Tanaka 1982). Int. J. Syst. Bacteriol. 47:1048-1054. 